\title{
A critical evaluation of environmental impact assessments: a case study of Goa mines, India
}

\author{
Mandar N. Datar ${ }^{1, *}$, Sujeet Dongre ${ }^{2}$ and Madhav Gadgil ${ }^{3}$ \\ ${ }^{1}$ Biodiversity and Palaeobiology Group, Agharkar Research Institute, G.G. Agarkar Road, Pune 411 004, India \\ ${ }^{2}$ The Centre for Environment Education, Bardez, Goa 403 521, India \\ ${ }^{3}$ National Centre for Cell Science, S.P. Pune University Campus, Pune 411 007, India
}

\begin{abstract}
Environmental impact assessments (EIAs) form the basis of estimation of environmental and socio-economic impacts of developmental projects. In this study we examine 65 EIA reports of mines in Goa. It is mandatory that the reports should provide, among others, lists of plant species from 314.2 and $78.5 \mathrm{sq} . \mathrm{km}$ area for lease areas of mines above 0.5 and below $0.5 \mathrm{sq}$. $\mathrm{km}$ respectively. On the basis of available data covering different spatial scales for the Western Ghats, we determined the species-area relationships, and expected number of species in area of these sizes. We find the plant lists in the EIA reports to be highly incomplete and defective in many ways, including with respect to information on water resources, and ore transport by trucks and barges. We conclude by recommending a set of measures focusing on transparency and public involvement to correct the situation.
\end{abstract}

Keywords: Developmental projects, environmental impact assessments, floristic diversity, mines, plant lists, species and area.

ENVIRONMENTAL impact assessment (EIA) is a key element in the toolkit developed by the Government of India (GoI) following the establishment of Ministry of Environment and Forests in the 1980s. In conjunction with public hearings, the EIAs are meant to deliver either of the following two tasks: (a) bring to notice avoidable negative environmental impacts so that a project may be reformulated, or (b) reject the project in case the negative environmental impacts, including socio-economic impacts are of such large magnitude that they outweigh the positive benefits of the proposed activity. The EIA notification of 1994 explicitly states that concealing factual data or submission of false or misleading data/reports, decisions or recommendations in a report would lead to the project being rejected. The entire process is being guided by sector-specific terms of reference and specific guidance manual prepared by the Administrative Staff College of India (ASCI), Hyderabad in 2010 (ref. 1).

Regretfully, there is abundant evidence that the whole EIA process today is sabotaged and incomplete, and often fraudulent and plagiarized information forms part of the

\footnotetext{
*For correspondence. (e-mail: mndatar@aripune.org)
}

EIA reports. Even reputed organizations like the National Environmental Engineering Research Institute (NEERI), CSIR laboratories, The Energy Research Institute (TERI), Ernst \& Young, Engineers India Limited (EIL), etc. have been involved in presenting fabricated data. For example, the EIA report for the Dandeli $18 \mathrm{MW}$ mini-hydel project in Karnataka prepared by Ernst \& Young was found to be based not only on fraudulent data, but also heavily plagiarized from another EIA report prepared for the Tattahalli Augmentation Scheme. Scanned pages of both these reports enumerating how pages after pages of one report were used for the second are available on the Environmental Support Group (ESG) website ${ }^{2}$. Interestingly, when this case was extensively highlighted by the media, TERI was engaged by the Government of Karnataka to prepare a fresh EIA, which again turned out to be based (in part) on fraudulent data ${ }^{3}$. In another example, the EIA submitted for Umbarshet bauxite mining in Ratnagiri, Maharashtra, in 2006 was found to be heavily plagiarized from a EIA report of a Russian aluminium company to mine bauxite in the Komi Republic of Russia, submitted to the European Bank in 2004. While located on an entirely different phytochorian, the Umbarshet bauxite mining EIA report reproduced, among others, even environmental data from the Russian report which included data on water quality, rainfall, animal densities and number of species ${ }^{4}$. Other fraudulent practices involving falsification of data in EIAs submitted in India and the secrecy around EIA reports have been widely documented $^{5-12}$. While serious deficiencies have been brought out in the case of many specific EIAs in this fashion, there is no comprehensive study available on the quality of a broader set of EIA reports. The present article represents such an attempt of looking at a set of EIA reports of 65 mines in Goa, India ${ }^{13}$.

\section{Materials and methods}

\section{Study area}

Goa, India's smallest state, is flanked to the east by the forested, biodiversity-rich Western Ghats and is adorned by nine rivers coursing through the hilly midlands and coastal plains with mangrove-fringed estuaries, and 
brackish- and sweet-water paddy fields. The hilly midlands are rich in iron and manganese ores that have been tapped over last sixty years with a large number of smallscale leases. The Western Ghats, considered one of the world's 34 hot spots of biodiversity, is second only to the Eastern Himalaya as a treasure trove of biological diversity in India ${ }^{14}$. Nearly 4000 species of flowering plants amounting to $27 \%$ of the country's total species are known from the Western Ghats. Of the 645 species of evergreen trees $(>10 \mathrm{~cm} \mathrm{dbh})$, about $56 \%$ are endemic to the Western Ghats. The great topographic heterogeneity and a strong rainfall gradient combine to support a tremendous diversity of life-forms and vegetation types in the Western Ghats, including tropical wet evergreen forest, montane stunted evergreen forest (shola) and grassland, lateritic plateaus, moist deciduous and dry deciduous forest, dry thorn forests, and grassland. Many of these are critical habitats for plants and animals: for instance, the heavily mined lateritic plateaus of Goa harbour unique floral elements as well as provide seasonal foraging grounds for large mammals such as the gaur. In recognition of this biodiversity wealth, the Western Ghats of Goa is largely protected by National Parks and Wildlife Sanctuaries.

Goa and the adjoining regions of Maharashtra and Karnataka have been well surveyed floristically. The significant studies include Vartak's ${ }^{15}$ enumeration of 1512 species from Goa, Sawantwadi state and Uttara Kannada, Karnataka; Rao's ${ }^{16}$ description of 1115 species from Goa; the Forest Research Institute's Forest Flora of Goa ${ }^{17}$ which includes 494 tree species, and Datar and Lakshminarasimhan's ${ }^{18-20}$ floristic study focusing on endemic plants of Bhagwan Mahavir National Park, Goa and adjoining areas. A number of recent studies document several new taxa, a majority from lateritic outcrops emphasizing the significance of these habitats ${ }^{21-25}$. As to adjoining localities, Kulkarni ${ }^{26}$ documented the flora of Sindhudurg district and Almeida ${ }^{27}$ that of Sawantwadi taluka. Studies of Uttara Kannada district in Karnataka list around 2000 species, 825 of them in Karwar, Kumta and Siddapur talukas (Subash Chandran and G. R. Rao, pers. commun.).

\section{Mining activities}

Over the years, a total of 79 mines located mainly in Bicholim, Sattari, Sanguem, Dharbandora and Quepem talukas covering approximately $700 \mathrm{sq}$. $\mathrm{km}$ have been in operation in Goa. This mining activity has been the focus of public concern in recent years, as reflected in Justice Shah Commission's report on illegal mining in Goa ${ }^{28}$. The report states that 'Part IV. Section 24 of the Mines and Minerals (DR) Act, 1957 was not observed at all and that no inspection was carried out of iron ore mines... which has caused loss to the ecology, environment, agri- culture, ground water, natural streams, ponds, rivers, biodiversity, etc.' As a part of the public scrutiny that this called for, the Government of Goa assigned responsibility to the Centre for Environment Education (CEE), Goa for (a) assessing the quality of the EIA submitted, and (b) compliance with environment clearance (EC) conditions and adequacy of the environmental management plans (EMP) with respect to mines in operation in Goa. The study, ably supported by the Department of Science, Technology and Environment, Government of Goa, enjoyed full cooperation of the mine management as well as people of the state.

\section{Methods}

The present study was conducted in a transparent and participatory manner and involved the following components: (1) Desk study of 79 EIA reports made available by Government of Goa. (2) Field visits to 17 of the 79 mining sites. (3) Field visits to nine villages affected by mining, of which six involved overnight stay in these villages that facilitated free, wide-ranging discussions with groups of local residents lasting well into the night. (4) A total of 15 Panchayats were requested to report their response on EIA, EC and EMP. Unfortunately none of them responded. (5) Group discussions with a wide range of stakeholders, including mine managers, and officials, Goa Mineral Foundation, ore transport truck owners, and drivers, farmers, fishermen, government officials, school and college students and teachers, over two years in large numbers. (6) Over 20 public lectures in educational institutions followed by open-mike discussions. (7) A full-day workshop with Youth Convention on Environment and Sustainability under the aegis of Goa Golden Jubilee Development Council.

While EIAs and ECs were available for all 79 mines, EMPs were not available for 14 of these mines. We have therefore presented here results from 65 mines for which EIA, EC and EMP data were available. These mines include mine leases with areas ranging over 0.24 to $8.26 \mathrm{sq}$. km. We mapped these mines to assess their vicinity to rivers and other water resources, and to 'protected areas' (Figure 1). The official guidelines classify the study area for assessing the impact of mining projects into two zones. The actual mine lease area is the 'core zone'; for mines with core zone of more than $0.5 \mathrm{sq} . \mathrm{km}$, the area within a radius of $10 \mathrm{~km}$ from the boundary limits of the lease is treated as the 'buffer zone'; and for mines with a core zone of less than $0.5 \mathrm{sq} . \mathrm{km}$, the area within a radius of $5 \mathrm{~km}$ from the boundary limits of the lease constitutes the 'buffer zone'. It is important to stress, however, that more pervasive impacts such as those involved in transport of the ores beyond the buffer zone must also be considered in the overall EIA. However, at a minimum, it is mandatory to survey the core 


\section{REVIEW ARTICLES}

plus buffer zones of $314.2 \mathrm{sq}$. km (for lease areas above $0.5 \mathrm{sq} . \mathrm{km}$ ) and $78.5 \mathrm{sq} . \mathrm{km}$ (for lease areas below $0.5 \mathrm{sq} . \mathrm{km}$ ) for biodiversity, and to provide both floral and faunal checklists. The majority of EIAs of mines give a checklist of flowering plants, whereas lower groups of plants are seldom reported.

We decided to assess in greater depth the quality of the checklists of flowering plants for the 65 mines. These pertain to areas of 314.2 or $78.5 \mathrm{sq}$. $\mathrm{km}$ depending on the mine lease area. Areas of such substantial sizes would be mosaics of habitats and would require systematic study of representative samples of each landscape/waterscape element type, estimating species richness levels of each landscape/waterscape element type, species turnover levels between different landscape/waterscape element types, and organized sampling effort to take seasonal turnover into account, local community members would certainly be aware of any such systematic studies. However, the citizen respondents consulted during the course of this study were unanimous in stating that they were not aware of any such an exercise being undertaken, and that data given in EIAs relating to social, economic aspects, biodiversity, agriculture and demography were often incorrect $^{13}$.

The quality and completeness of reported lists of flowering plants may be assessed by comparing them with the expected number of species and their composition in terms of preferred habitats/growth forms. The numbers to be expected can be predicted on the basis of available

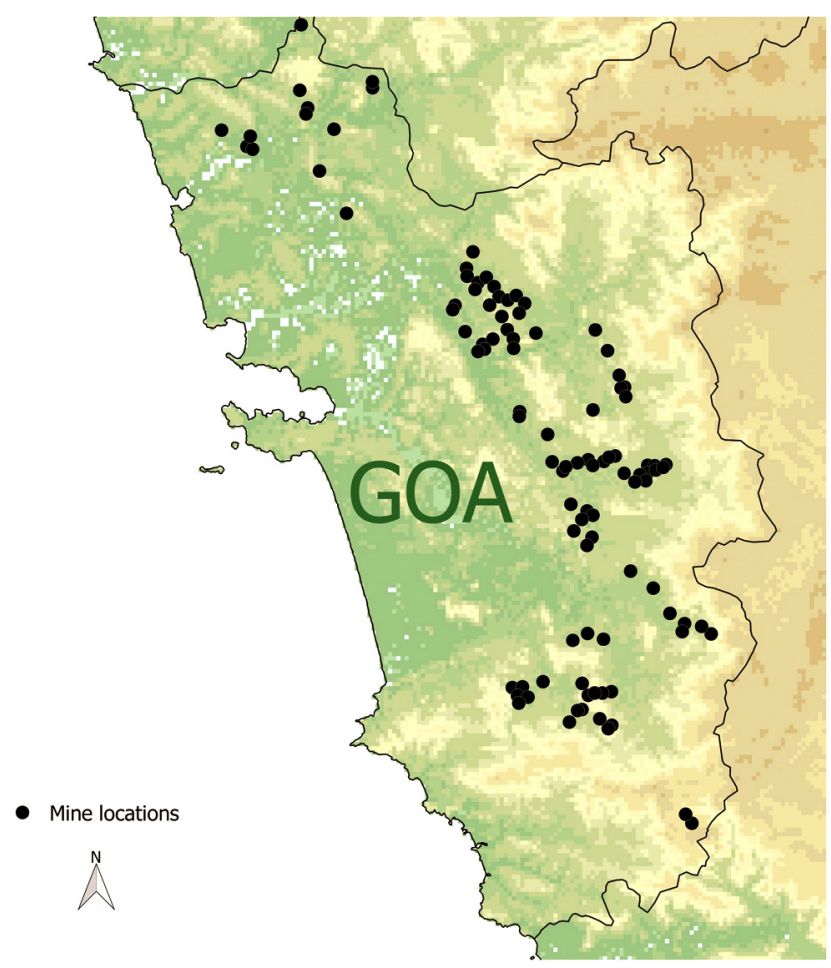

Figure 1. Location of existing and proposed mines in Goa, India. data covering different spatial scales, since the relationship between species richness and the area under study is well described by $S=C A^{z}$, where $S$ represents the number of species and $A$ is the size of the study area. The resulting $\log -\log$ curve is linear with slope $z$, which may take values from 0 to 1 , but is often $\sim 0.26$ (refs 29-32).

We compiled a comprehensive checklist of flowering plants from reports of all 65 mines and from the published literature as well as personal communications with a focus on Goa and adjoining areas from the northern and central Western Ghats ${ }^{16,17,19,20,26,27,33-37}$ (Table 1). To these checklists was added information on (a) habit groups like herbs, shrubs, trees and climbers; (b) Raunkiaer life-forms ${ }^{38}$; (c) preferred habitats like evergreen forests, semi-evergreen forests, moist deciduous forests, open areas, marshy areas, mangroves and plateaus, and (d) endemic and threatened status of species.

\section{Results and discussion}

\section{Manifold deficiencies}

EIA exercises, mandated under the Environment (Protection) Act 1986, are aimed at protecting the environment, defined as including water, air and land and interrelationships which exist among and between water, air and land and human beings, other living creatures, plants, microorganisms and property. Thus, the scope of the EIA exercise is broad, and the guidelines specifically mention that 'Vehicular traffic density outside the mine lease area, existing and after beginning of the mining activities should be given. The mode of transport of mineral and waste including loading, unloading in mining area should also be discussed. Vehicular load must be calculated. Further, the mineral transportation outside the mining lease area (road, rail, conveyor, rope way, water way, pipeline, etc.) may be specified, 1 .

Mining has substantial impacts that pervade through entire Goa, impacting the Western Ghats, the midland plateaus and coastal regions, land and water, forests, agriculture and human settlements. These need to be

Table 1. Areas of various regions and species of angiosperms reported

\begin{tabular}{lrc}
\hline Region & Area (sq. km) & Angiosperm species \\
\hline Western Ghats & 160,000 & 5,588 \\
Uttar Kannada & 10,291 & 2,000 \\
Kolhapur & 7,685 & 2,227 \\
Raigad & 7,152 & 1,136 \\
Sindhudurg & 5,207 & 1,123 \\
Goa & 3,702 & 1,373 \\
Sawantwadi & $1,336.2$ & 1,685 \\
Bhagwan Mahavir National Park & 240 & 722 \\
Sanjay Gandhi National Park & 104 & 1,109 \\
\hline
\end{tabular}


viewed in a comprehensive and integrated manner, if the environmental impact of mining is to be adequately assessed and addressed through appropriate management measures. Such a holistic view has been lacking, and all the mines-related EIAs completely neglect the following important issues:

(1) Loss of agricultural productivity due to (a) deposition of dust on the leaves, (b) depletion of groundwater and water supply, (c) destruction of springs and other water sources, (d) siltation of agricultural land and orchards, (e) breaking of estuarine khazan land bunds due to ore barge traffic movement in rivers, (f) oil pollution of water and soil, and (g) excess iron and manganese content in water and soil.

(2) Destruction of grazing resources for livestock.

(3) Loss of fish and shellfish productivity due to (a) turbidity in water, (b) increased sedimentation and (c) oil, iron and manganese pollution.

(4) Destruction of sacred groves.

(5) Destruction of unique ecological habitats like hill plateaus and hill streams.

(6) Decrease in the productivity of forest vegetation due to air pollution and deposition of dust layer on the leaves.

(7) Noise and vibration leading to disturbance to wildlife and its movement.

(8) Impact on coastal fisheries of increased riverine barge traffic and increased ore loading points, and of barge and ship movement in the coastal and offshore waters.

(9) Reduction in availability of land-based as well as aquatic wild food to people.

(10) Traffic congestion and road accidents.

(11) Impacts of air, water and noise pollution on human health.

(12) Loss of employment in fisheries, agriculture, horticulture and forestry sector.

(13) Social conflicts resulting from unequal distribution of economic gains, influx of immigrants and increased liquor sales.

Furthermore, the EIAs suffer from the following issues:

(1) Improper documentation of the existence of water sources within mine leases and adjoining the leased boundary.

(2) Improper documentation of information relating to demographic profile and socio-economic status.

(3) Discrepancies with respect to actual distances between the boundaries of mine leases and protected areas.

(4) Improper documentation of the flora and fauna of the mine lease and buffer areas.

(5) Inadequate air, noise and water monitoring.
For example, T.C. No. 01/51 belonging Shaikh Salim and situated at Devpan Dongor of Caurem village in Quepem taluka, does not make any mention of the existence of two perennial water springs within the mining leased area. The EC has a specific condition in the letter not to disturb the water spring and maintain $50 \mathrm{~m}$ of natural vegetation on each side and enrich this area by planting native species of vegetation. This condition is completely violated.

\section{Documentation of angiosperm species}

Species richness: Species-area relationship effectively predicts the number of species in areas of various sizes $^{30,31}$. The checklists of angiosperms from the EIAs of the 65 mines are expected to represent the number of species occurring in buffer zone areas of either 314.2 or $78.5 \mathrm{sq} . \mathrm{km}$ depending on the mine lease area. The expected number of angiosperm species in areas of sizes of these buffer zones can be predicted on the basis of regression of the number of species against areas of localities of various sizes using the following equation, $\log (S)=$ $\log (C)+z^{*} \log (A)$, where $S$ is the species number, $C$ the intercept, $z$ the slope and $A$ is the area. As noted earlier in the text, we do have such information for areas ranging in size from $160,000 \mathrm{sq} . \mathrm{km}$ for the Western Ghats to 104 sq. km for Sanjay Gandhi National Park. The resultant regression equation has an intercept $C=263.25$ and the slope $z=0.22$. Thus, the expected number of species occurring in 314.2 sq. $\mathrm{km}$ area is 932 , while that for an area of 78.5 sq. km is 687 (Figure 2). However, it may be noted that due to limitations of dataset, it was difficult to assign meaningful confidence intervals. These numbers may be compared with the number of species reported from the mines to understand how incomplete these lists are. The maximum number reported is 187 species for

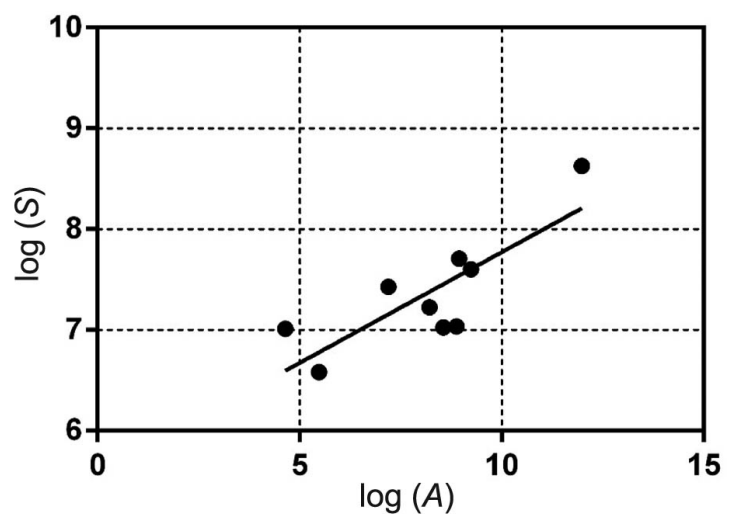

Figure 2. Species-area fit based on species recorded in major areas of the Western Ghats. Fit: $\log (S)=\log (C)+z^{*} \log (A)$, where $C=263.25 ; z=0.22 ; S(314.2)=932 ; S(78.57)=687(\mathrm{RSME}=750$; correlation coefficient $=0.91$, where $S$ represents the number of species, $A$ the size of the study area and $z$ is the slope of the resulting loglog curve. 
Suctoli-(Sailetembo), while Sigao Iron Ore Mine reported only 3 species, and majority of the mines reported less than 50 species. Apparently, all these are extremely incomplete and underestimated lists (Figure 3).

\section{Composition}

Given that the lists are very incomplete, one may enquire as to whether there was specific bias in these reports towards underreporting species diversity. Four of the available floristic lists, i.e. for Bhagwan Mahavir National Park, Goa, Uttara Kannada and Sindhudurg districts furnish adequate data to estimate the number of total species, endemic species, threatened species, trees, lianas, herbs, shrubs, climbers, phenerophytes, cryptophytes and therophytes. The numbers may be predicted using the equation $\log \left(S_{i}\right)=\log (C)+z^{*} \log (A)$, where $S_{i}$ is the number of species of $i$ th category such as endemic, threatened, shrubs, therophytes, etc. $C$ the intercept, $z$ the slope and $A$ is the area. These predicted numbers were compared with the actual numbers for those categories reported from various mines, underlining serious underrepresentation overall, and especially for endemic and threatened species, and herbs, cryptophytes and therophytes (Table 2). We also compared the relative proportions of the various categories in the composite mine checklist with those for Bhagwan Mahavir National Park, which has an area of the same size as buffer zones of the mines. Table 3 reports this statistics as ((number of species in the $i$ th category/total number of species in the composite mine checklist)/(number of species in the $i$ th category/total number of species in Bhagwan Mahavir National Park)). Trees and lianas (phenerophytes) and non-native species form a greater proportion, while endemic and threatened species constitute a smaller proportion reported compared to flora in the Bhagwan Mahavir National Park. The herbs (therophytes) too are underrepresented, suggesting inadequate survey in monsoon or post-monsoon season.

\section{Discrepancies}

Many discrepancies, often glaring, are noticeable in the angiosperm checklists provided in the reports. Many lists are simply repeated from other EIA reports. Just to cite a few representative examples, three reports, viz. those for Saniem-Sacorda Iron Ore Mine, Cuddegal-Voril-Soddo and Copila-Gaichens carry identical lists of 138 species. Three other reports, viz. those for Shigao Iron Ore Mine, Huldol Dongor-Bimbol Iron Ore Mine, Marga-FondculOu-Chicolmolo Mine also carry identical lists of 39 species. Some species, e.g. Eriolaena candollei, Euphorbia indica, Euphorbia orbiculata, Fagonia cretica, and Grewia tenax, never reported earlier in any of the floras of Goa region ${ }^{16-20}$, are included in mine checklists suggest- ing either misidentification or fabrication of data without even visiting the site. Hyphaene dichotoma, a palm only restricted to coastal habitats, finds a place in the Gautona-Dusrifall Iron Ore Mine checklist. Many species like Erythrina variegata, Ficus lacor, Flacourtia jangomas, and Gossypium herbaceum are only under cultivation in Goa; these are included in mine checklists as wild species. Species like Acacia nilotica, Boswellia serrata, and Capparis deciduas, which are inhabitants of drier regions of peninsular India and do not occur in Goa also find a place in some mines checklists, suggesting that some of the checklists are copied from EIA reports of other states. Similarly, the endemic species of cane Calamus lakshmanae Renuka, occurring only in much wetter evergreen forests of Karnataka and Kerala, is recorded in the EIA report of Mollatembo-Naquerim-Rivona Iron Ore Mine.

\section{Way ahead}

There are serious deficiencies in the EIA reports, and it is imperative that we take appropriate steps to remedy them. Specifically, the process of generating these reports must become transparent and involve full participation of local communities. As the whole process is aimed at fulfiling the social objectives of promoting environmentally and socially sustainable development, it should examine any development intervention in the broader context of other such on-going interventions and processes, as also the broader environmental and socio-economic context. It should stimulate proper scrutiny of various possible alternatives for meeting a particular development objective, such as mining of iron ore or construction of a highway or generation of thermal power, in order to lead to the selection of the most desirable alternative, namely one that maximizes the net gain from the development intervention, i.e. maximizes the balance of economic, environmental, social benefits minus the economic, environmental, social costs. If the balance is considered substantial enough to justify the intervention, the most desirable alternative should be selected, and the project accepted while specifying due safeguards. Otherwise, the
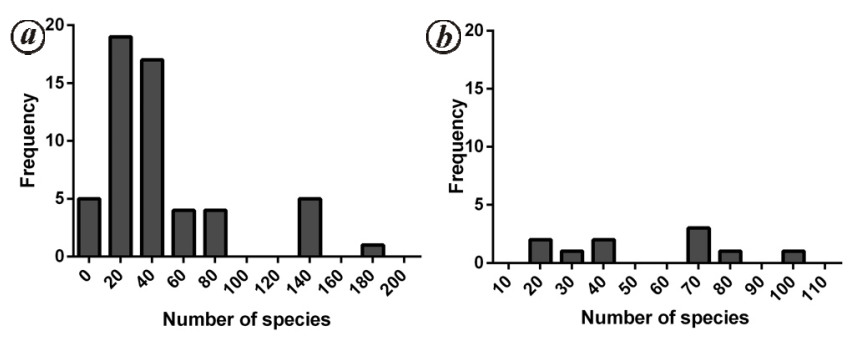

Figure 3. Frequency distribution of number of species reported from mines: (a) for areas above $0.5 \mathrm{sq} . \mathrm{km}$, and (b) for areas below $0.5 \mathrm{sq} . \mathrm{km}$. The plot highlights serious underrepresentation in the mine flora when the predicted numbers are 932 and 687 for areas above 0.5 and below 0.5 sq. $\mathrm{km}$ respectively. 
Table 2. Comparative chart showing the mean, mode and median as also maximum and minimum values of recorded number of plants in mines, along with the predicted numbers. Note that the mine with the maximum number of species is not even close to the predicted number for each group, suggesting heavy underrepresentation

\begin{tabular}{|c|c|c|c|c|c|c|c|}
\hline Category & Mean & $\begin{array}{l}\text { Standard } \\
\text { deviation }\end{array}$ & Mode & Median & $\begin{array}{c}\text { Maximum number } \\
\text { of species }\end{array}$ & $\begin{array}{l}\text { Minimum number } \\
\text { of species }\end{array}$ & $\begin{array}{l}\text { Predicted } \\
\text { number }\end{array}$ \\
\hline Endemic species & 3.77 & 5.64 & 1 & 3 & 42 & 0 & 139 \\
\hline Threatened species & 0.09 & 0.42 & 0 & 0 & 3 & 0 & 21 \\
\hline Trees & 31.97 & 24.4 & 33 & 33 & 113 & 1 & 207 \\
\hline Lianas & 1.69 & 2.21 & 2 & 2 & 16 & 0 & 28 \\
\hline Herbs & 5.25 & 12.01 & 0 & 1 & 60 & 0 & 335 \\
\hline Climbers & 1.77 & 2.97 & 0 & 0 & 14 & 0 & 60 \\
\hline Phenerophytes & 38.92 & 29.92 & 37 & 37 & 131 & 3 & 368 \\
\hline Cryptophytes & 0.91 & 1.82 & 0 & 0 & 12 & 0 & 46 \\
\hline Therophytes & 6.11 & 12.88 & 0 & 2 & 64 & 0 & 346 \\
\hline
\end{tabular}

Table 3. Proportion of species in various categories for the composite mine checklist divided by their proportions in the checklist for Bhagwan Mahavir National Park, i.e. ((number of species in the $i$ th category/ total number of species in the composite mine checklist)/(number of species in the $i$ th category/total number of species in Bhagwan Mahavir National Park))

\begin{tabular}{ll}
\hline Non-native & 3.257778 \\
Trees & 1.588388 \\
Phenerophytes & 1.359177 \\
Lianas & 1.252991 \\
Moist deciduous forest species & 1.038043 \\
Shrubs & 1.02167 \\
Evergreen/semi-evergreen forest species & 0.824211 \\
Wild & 0.816847 \\
Open-area species & 0.767138 \\
Climbers & 0.764537 \\
Therophytes & 0.68345 \\
Herbs & 0.648099 \\
Cryptophytes & 0.584729 \\
Endemics & 0.553859 \\
Plateau species & 0.514048 \\
Marshy & 0.302446 \\
Threatened species & 0.298331 \\
\hline
\end{tabular}

project should be rejected. An on-going monitoring of the consequences of the project, including environmental and socio-economic impacts should be put into place to ensure that the stipulated safeguards are being adequately implemented. Moreover, in real life many unforeseen impacts may materialize and the monitoring process should be so designed as to bring them out. In order to ensure that this is properly taken into account, the environmental clearances should not be granted once for all, but should be reviewed periodically, for instance, every five years. The proponents of the project should not be permitted to make substantial changes to it without due EIA of the changes proposed.

We suggest therefore that the Ministry of Environment, Forest and Climate Change, GoI take the following steps:
(1) Encourage local bodies, i.e. Gram, Taluk and Zilla Panchayats and Municipal Councils and City Corporation to prepare ward-level status of environment reports, and assign to them a key role in the EIA process, including monitoring the implementation of the environmental management plans.

(2) Assign to Biodiversity Management Committees (BMCs) in all local bodies, fully empowered under the Biological Diversity Act, 2002, the task to regulate the use of local biodiversity resources and to charge collection fees, and a key role in the EIA process, including monitoring the implementation of the environmental management plans.

(3) Reinstate the system of empowering citizens to monitor status of the environment under environmental monitoring schemes such as 'Paryavaran Vahini' of the Ministry of Environment and Forests, Government of Goa.

(4) Carry out a radical reform of the EC process through (a) assigning preparation of EIA statements to a neutral competent body that does not depend on payment by project proponents; (b) making mandatory the involvement of local BMCs in the EIA preparation process; (c) making mandatory to consider all information submitted and suggestions made during public hearings; (d) making mandatory periodic environmental clearance requirement, preferably every five years; (e) making mandatory the involvement of local BMCs in the process of monitoring the implementation of conditions laid down while granting ECs, and (f) making mandatory the preparation of regional cumulative EIAs.

(5) Organize a transparent, participatory database on the Indian environment by making public all pertinent information with government departments, and the environment status reports, people's biodiversity registers, community forest management working schemes, and environmental education projects undertaken by students. 
1. ASCI, Mining and beneficiation of minerals. Environmental Impact Assessment Guidance Manual, Administrative Staff College of India, Hyderabad, 2010.

2. ESG, The Dandeli EIA fraud. Environment Support Group Trust, Bengaluru, 2000; http://static.esgindia.org/campaigns/dandeli/docs. htm

3. Daniels, R., Evaluation of the environment impact assessment conducted by Tata Energy Research Institute, Bangalore for the Dandeli mini-hydel project of M/s Murdeshwar Power Corporation Ltd across River Kali near Dandeli in Uttara Kannada district, Karnataka, 2000; http://static.esgindia.org/campaigns/dandeli/ docs/Daniel\%20TERI\%20Note.htm

4. Dutta, R. and Sreedhar, R., A framework for EIA reforms in the Western Ghats. EIA Resource and Response Centre, New Delhi, 2011 .

5. Kohli, K. and Menon, M., Eleven years of the Environment Impact Assessment Notification, 1994; How Effective Has It Been. Kalpavriksh Environmental Action Group, New Delhi, 2005.

6. Dutta, R., First report on the Rufford's Innovation Grant National Level Environment Impact Assessment Response Centre, 2007.

7. Dutta, R., Second report on the Rufford's Innovation Grant National Level Environment Impact Assessment Response Centre, 2008 .

8. Swidesrka, K., Roe, D., Siegele, L. and Grieg-Gran, M., The Governance of Nature and the Nature of Governance: Policy that Works for Biodiversity and Livelihoods, Vol. 8, International Institute for Environment and Development, London, UK, 2008, p. 169.

9. Bindra, P., Environmental clearance report. Tehelka Mag., 2009; http://archive.tehelka.com

10. Mukherjee, P., EIA scams: decaying the EIA legal regime in India. J. Environ. Res. Dev., 2012, 6(3), 507-513.

11. HRW, Out of control: mining, regulatory failure, and human rights in India. Human Rights Watch, NY, USA, 2012, pp. 36-40.

12. Dutta, R., Quality of EIA reports a major concern. Frontline, 2014, 31(3), 18.

13. Gadgil, M. and Dongre, S., Report of research project on assessing quality of environmental impact assessment (EIA), compliance of environmental clearance (EC) conditions and adequacy of environmental management plan (EMP) of mining industry in Goa mimeographed report, 2013.

14. Myers, N., Mittermeier, R. A., Mittermeier, C. G., Da Fonseca, G. A. and Kent, J., Biodiversity hotspots for conservation priorities. Nature, 2000, 403, 853-858.

15. Vartak, V. D., Enumeration of Plants from Gomantak, MACS, Pune, India, 1966, p. 76.

16. Rao, R. S., Flora of Goa, Diu, Daman, Dadra and Nagarhaveli. In Flora of India, Series, 2, Botanical Survey of India, New Delhi, 1985.

17. Naithani, H. B., Sahni, K. C. and Bennet, S. S. R., Forest Flora of Goa, International Book Distributors, Dehradun, 1997, p. 666.

18. Datar, M. N. and Lakshminarasimhan, P., Endemic plants of Bhagwan Mahaveer National Park, Goa - an analysis based on their habitat, phenology and life form types. Indian For., 2011, 137(12), 1451.

19. Datar, M. N. and Lakshminarasimhan, P., Flora of Bhagwan Mahavir (Molem) National Park and Adjoinings, Goa, Botanical Survey of India, 2013, p. 314.

20. Datar, M. N. and Lakshminarasimhan, P., Check list of wild angiosperms of Bhagwan Mahavir (Molem) National Park, Goa, India [with erratum]. Check List, 2013, 9(2), 186-207.
21. Janarthanam, M. K., Joshi, V. C. and Rajkumar, S., Glyphochloahenryi, a new species of Poaceae from Goa, India. Rheedea, 2000, 10(2), 99-102.

22. Fonseca, M. A. and Janarthanam, M. K., A new species of Glyphochloa WD Clayton (Poaceae) from Goa, India. Rheedea, 2003, 13, 35-38.

23. Gad, H. S. and Janarthanam, M. K., A new species of Ischaemum (Poaceae) from Goa, India. Kew Bull., 2007, 62, 499-501.

24. Raj, K. M. S. and Sivadasan, M., A new species of Dimeria R. Br. (Poaceae-Panicoideae-Andropogoneae) from Goa, India. Novon, 2008, 18(2), 183-186.

25. Prabhugaonkar, A., Yadav, U. S. and Janarthanam, M. K., Dipcadi goaense (Hyacinthaceae), a new species from the foothills of the Western Ghats, India. Kew Bull., 2009, 64(4), 743-746.

26. Kulkarni, B. G., Flora of Sindhudurg, Botanical Survey of India, Calcutta, 1988.

27. Almeida, S. M., The Flora of Sawantwadi, Maharashtra, India, Scientific Publishers, Jodhpur, 1990, p. 304.

28. Shah Commission, The report of the Justice M B Shah Commission of Inquiry on illegal mining in the state of Goa. Ministry of Mines, Government of India, 2012.

29. Arrhenius, O., Species and area. J. Ecol., 1921, 9(1), 95-99.

30. Gleason, H. A., Species and area. Ecology, 1925, 6(1), 66-74.

31. Connor, E. F. and McCoy, E. D., The statistics and biology of the species-area relationship. Am. Nat., 1979, 113(6), 791-833.

32. Drakare, S., Lennon, J. J. and Hillebrand, H., The imprint of the geographical, evolutionary and ecological context on species-area relationships. Ecol. Lett., 2006, 9(2), 215-227.

33. Nayar, T. S., Rasiya, B. and Sibi, M., Flowering Plants of the Western Ghats, India, Volume 1: Dicots, Jawaharlal Nehru Tropical Botanical Garden and Research Institute, Thiruvananthapuram, 2015, p 934.

34. Nayar, T. S., Rasiya, B. and Sibi, M., Flowering Plants of the Western Ghats, India, Volume 2: Monocots, Jawaharlal Nehru Tropical Botanical Garden and Research Institute, Thiruvananthapuram, 2015, pp. 935-1683.

35. Kothari, M. J. and Moorthy, S., Flora of Raigad District, Maharashtra State, Botanical Survey of India, Calcutta, 1993.

36. Pradhan, S. G., Sharma, B. D. and Singh, N. P., Flora of Sanjay Gandhi National Park, Borivali, Mumbai (Bombay), Botanical Survey of India, 2005.

37. Sardesai, M. M. and Yadav, S. R., Flora of Kolhapur District, Shivaji University, Kolhapur, 2002.

38. Cain, S. A., Life-forms and phytoclimate. Bot. Rev., 1950, 16(1), $1-32$.

ACKNOWLEDGEMENTS. M.N.D. thanks the Director, Agarkar Research Institute, Pune for facilities and encouragement and G. R. Rao, M.E.S. College, Bengaluru for sharing data on angiosperms of Uttar Kannada, Karnataka. M.G. and S.D. thank Aleixo Sequiera (former Minister for Environment, Goa) for support and encouragement; Michael D'Souza (Joint Secretary (Finance), GoI) and the Department of Science, Technology and Environment, Government of Goa for supporting the study. M.G. and S.D. thank Sanjeev Joglekar (Goa State Pollution Control Board (GSPCB)) for providing all the EIA, EC and EMP documents and Dr Mohan Girap (GSPCB) for critical comments on the analysis tool.

Received 12 December 2018; revised accepted 6 May 2019

doi: $10.18520 / \mathrm{cs} / \mathrm{v} 117 / \mathrm{i} 5 / 776-782$ 